\title{
Covid-19: Campaigner calls for national guidance to stop DNR orders being made without discussion with patients and families
}

\author{
Clare Dyer
}

The BMJ

The daughter of a man who successfully fought to establish that patients have a right to be consulted on cardiopulmonary resuscitation (CPR) has launched a High Court challenge against Matt Hancock, the health and social care secretary for England.

Kate Masters has written a letter before action to Hancock after news reports suggested that blanket bans on CPR were being imposed during the covid-19 pandemic.

In the letter, she called on Hancock to give an emergency direction to all healthcare professionals providing that "do not attempt cardiopulmonary resuscitation" (DNACPR) orders must not be imposed unless the patient or family have been consulted and certain information provided.

This must include making clear the fact that the patient's consent is not required for a DNACPR order is added to their notes, the relevance of clinical judgment, and how resource constraints are taken into account, she argues. The patient must be informed of the DNACPR decision and the reasons why, which must be individual to the patient, who can request a second opinion.

Masters is the daughter of David Tracey, who took University Hospitals Cambridge NHS Foundation Trust to the High Court and Court of Appeal after his wife, Janet, who had terminal lung cancer, had a DNACPR notice put in her records at Addenbrooke's Hospital without consultation.

The appeal court declared in 2014 that the trust had violated her rights under article 8 of the European Convention on Human Rights in failing to involve her in the process. The court held that the patient must be involved unless the doctor thinks that this would cause distress and that the distress might cause the patient harm.
Masters said, "I have watched with alarm as reports of blanket DNR orders in care homes and failures to consult with patients and their families have been reported in the news since the start of the coronavirus crisis. After all my dad did to clarify the law regarding DNRs, I am determined to ensure that my human rights and those of others are not breached because of a lack of government direction."

She argues in her letter that legal requirements are not being met and human rights are being violated, or at significant risk of being violated, on a widespread basis during the pandemic. She has ongoing health problems and members of her family have serious conditions; she says she is at significant risk of decisions being made without proper process.

With NHS trusts and their staff under unprecedented strain, she says, a lack of clear national guidance or policy adds to the burden.

She has asked Hancock for a response by 7 May. If no satisfactory reply is received, she said she would consider bringing a judicial review case in the High Court.

Her solicitor, Merry Varney of the law firm Leigh Day, said, "Our client believes it's time for the government to step up and give national guidance that will ensure consistent and lawful decision making at a local level and also ensure patients' fundamental human rights are being upheld."

1 David Tracey $v$ University Hospitals Cambridge NHS Foundation Trust and Secretary of State for Health. 2014. www.bailii.org/cgi-bin/format.cgi?doc=/ew/cases/EWCA/Civ/2014 33 .

Published by the BMJ Publishing Group Limited. For permission to use (where not already granted under a licence) please go to http://group.bmj.com/group/rights-licensing/ permissions 